\title{
Perinatal Outcomes of Advanced and Extremely Advanced Maternal Age Pregnancies
}

\author{
Ileri ve Çok Ileri Anne Yaşı Gebeliklerinin Perinatal Sonuçları
}

\author{
๑ Burcu Dinçgez Çakmak, • Betül Dündar, • Ülkü Ayşe Türker \\ University of Health Sciences, Bursa Yüksek Ihtisas Training and Research Hospital, Clinic of Gynecology and Obstetrics, Bursa, Turkey
}

\section{Abstract}

Aim: Advanced and extremely advanced maternal age (AMA, EAMA) are known to be associated with increased perinatal mortality and morbidity. We aimed to compare the perinatal outcomes of pregnancy in women $<35$ and $\geq 35$ years of age and also to compare the outcomes between AMA and EAMA pregnancies.

Methods: A total of 1202 patients, who had regular antenatal follow-up and gave birth in our clinic between June 2016 and December 2017, were included. The study group consisted of 632 patients aged $\geq 35$ years and control group consisted of 570 patients aged $<35$ years. Then, the patients were divided into two subgroups; patients aged $35-40$ years $(n=495)$ and over 40 years $(n=137)$. Socio-demographic features, delivery characteristics and perinatal outcomes were obtained from the medical records. Perinatal outcomes were compared between patient and control groups and between subgroups.

Results: Gestational diabetes (GDM) $(p<0.001)$, preeclampsia $(p<0.001)$, placenta previa (PP) $(p=0.03)$ and intrauterine fetal death (IFD) $(p<0.001)$ were more common in AMA group than in controls. In subgroup analysis, cesarean section rate was higher $(p<0.001)$, IFD $(p=0.04), \operatorname{PP}(p<0.001)$, preeclampsia $(p<0.001)$ and GDM $(p<0.001)$ were more common in EAMA group than in AMA group.

Conclusion: Adverse perinatal outcomes are more common in AMA and EAMA pregnancies. We suggest that close monitoring of these pregnants in the antenatal period is crucial to avoid adverse outcomes and to prevent perinatal mortality and morbidities.

Keywords: Advanced maternal age, extremely advanced maternal age, perinatal outcomes

\section{Öz}

Amaç: ileri ve çok ileri anne yaşı gebelikleri (IAY, çiAY) artmış perinatal mortalite ve morbidite ile ilişkilidir. Çalışmamızda, 35 yaşın altındaki ve üzerindeki gebeliklerin ve ayrıca IAY, ÇIAY'nin perinatal sonuçlarının karşılaştırılması amaçlanmıştır.

Yöntemler: Çalışmaya Haziran 2016 ve Aralık 2017 tarihinde kliniğimizde takip edilen ve doğumu gerçekleştirilen 1202 hasta dahil edildi. Çalışma grubu $\geq 35$ yaşındaki 632 gebeden ve kontrol grubu <35 yaşındaki 570 gebeden oluşmaktaydı. Hasta grubu da 35-40 yaş arasındaki gebeler $(n=495)$ ve 40 yaşın üzerindeki gebeler ( $n=137$ ) olmak üzere iki alt gruba ayrıldı. Hastaların sosyodemografik özellikleri, doğum özellikleri ve perinatal sonuçları medikal dosyalarından kaydedildi. Perinatal sonuçlar hasta ve kontrol grubu arasında ve ayrıca alt gruplar arasında karşılaştırıldı.

Bulgular: Gestasyonel diyabet $(p<0,001)$, preeklampsi $(p<0,001)$, plasenta previa $(p=0,03)$ ve intrauterin fetal ölüm $(p<0,001)$ ileri maternal yaş grubunda kontrol grubuna göre istatistiksel anlamlı olarak daha sıktı. Alt grup analizinde, sezaryen oranı daha yüksek iken $(p<0,001)$, benzer şekilde intrauterin fetal ölüm $(p=0.04)$, plasenta previa $(p<0,001)$, preeklampsi $(p<0,001)$ ve gestasyonel diyabet $(p<0,001)$ de çok ileri anne yaşı grubunda, ileri anne yaşı grubundan daha sık olarak tespit edildi.

Sonuç: IAY, çiAY'de olumsuz perinatal sonuçlar daha sık görülmektedir. Antenatal dönemde bu hastaların yakın takibinin bu olumsuz sonuçlardan korunmada ve perinatal mortalite ve morbidite artışını önlemede kritik rolü olduğunu düşünmekteyiz.

Anahtar Sözcükler: İleri anne yaşı, çok ileri anne yaşı, perinatal sonuçlar
Address for Correspondence/Yazışma Adresi: Burcu Dinçgez Çakmak, University of Health Sciences, Bursa Yüksek Ihtisas Training and Research Hospital, Clinic of Gynecology and Obstetrics, Bursa, Turkey

E-mail: burcumavis@gmail.com ORCID: orcid.org/0000-0002-2697-7501

Received/Geliş Tarihi: 11 January 2019 Accepted/Kabul Tarihi: 18 February 2019

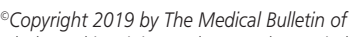
istanbul Haseki Training and Research Hospital The Medical Bulletin of Haseki published by Galenos Yayınevi.

${ }^{8}$ Telif Hakkı 2019 istanbul Haseki Eğitim ve Araştırma Hastanesi Haseki Tıp Bülteni, Galenos Yayınevi tarafından yayınlanmıştır. 


\section{Introduction}

Advanced maternal age (AMA) is defined as childbearing in a woman over 35 years of age while extremely advanced maternal age (EAMA) is defined as pregnancy in those over 40 years of age by the International Federation of Gynecology and Obstetrics (1).

The incidence of AMA is reported to be $12.6 \%$ in England, 33.4\% in Norway, 11.4-19.1\% in Taiwan and it varies from $8.6 \%$ to $11.8 \%$ in our country. For EAMA, it has been reported to be $4 \%$ in England $(2,3)$. According to the Civil Registration and Nationality Services of Turkey, $2.3 \%$ of all pregnancies were in women at EAMA in 2009 and this reached to $2.8 \%$ in 2014 (4).

Delayed childbearing has been an increasing trend in developed countries due to social, financial and educational status of women. Moreover, late miscarriages, career goals, advanced assisted reproductive techniques and ineffective contraception in multiparous women are the main risk factors for AMA and EAMA (5-7).

AMA and EAMA are known to be associated with increased maternal and fetal mortality and morbidity. Previous studies reported that they were related with hypertensive disorders of pregnancy, gestational diabetes mellitus (GDM), postpartum hemorrhage, placenta previa (PP), low birth weight, intrauterin growth restriction, prematurity, macrosomia, low Apgar scores and increased cesarean section rates (8-13). Although adverse perinatal outcomes are more common in AMA and EAMA, these outcomes could generally be avoided with advanced neonatal care units and close monitoring of pregnants in the antenatal period.

In this study, we aimed to compare the perinatal outcomes of pregnancy in women under and over 35 years of age and also to compare the outcomes between AMA and EAMA.

\section{Methods}

This is a retrospective observational case-control study, conducted in a high-volume university-affiliated training and research hospital between June 2016 and December 2017. Ethics committee approval is not required for retrospective studies in our country but we commit that this study complies with the declaration of Helsinki. Informed consent was routinely obtained from patients during their admission which includes the participation in scientific studies.

In this study, a total of 1202 patients, who had a regular antenatal follow-up and gave birth in our clinic, were included. The study group was composed of 632 patients aged 35 years and over and control group was composed of 570 patients younger than 35 years. Then, the patients were divided into two subgroups as; patients aged 35-40 years $(n=495)$ and patients over 40 years of age $(n=137)$. Patients with cardiac diseases, chronic hypertension, hypohyperthyroidism, Diabetes mellitus, congenital uterine anomalies, multiple pregnancies, hepatic and renal failure, prior placental abnormalities, previous preterm birth, recurrent pregnancy loss, hematological and auto-immune diseases and alcohol or cigarette habits were excluded.

The patients' gravidity, parity, delivery mode, gestational age at delivery, birth weight, presence of premature rupture of the membrane, PP, pre-eclampsia, GDM, intrauterine pregnancy loss, Apgar scores at the first and fifth minutes, presence of respiratory distress syndrome, sepsis, and neonatal intensive care unit admission were obtained from the medical records. The perinatal outcomes were compared between patient and control groups and also between subgroups.

\section{Statistical Analysis}

Statistical analyses were performed by using the SPSS statistical software version 21.0 (Statistical Package for the Social Sciences, Chicago, IL). The Kolmogorov-Smirnov test was carried out to evaluate the normality of variables. Normally distributed variables were expressed as mean \pm standard deviation, non-normally distributed ones as median and categorical variables were expressed as percentage. For group comparison, the Mann-Whitney $U$ test was performed to compare non-normally distributed parameters and the chi-square test for categorical variables. A $p$ value of less than 0.05 was considered statistically significant.

\section{Results}

The mean age of the study participants was $31.55 \pm 11.63$ years, median gravidity was $3(1: 7)$ and the mean parity was $2(1: 7)$. The mean birth weight was 3108.2 \pm 517.2 grams and gestational week at birth was 37 (28:40). Assisted reproductive techniques were performed in 69 patients (5.7\%). Intrauterine fetal death was determined in $34(2.8 \%)$ patients, PP in 27 (2.2\%), pre-eclampsia in 108 (8.9\%), GDM in 75 (6.2\%), premature rupture of the membrane in $73(6.1 \%)$, preterm delivery before 34 weeks in 96 (7.9\%) and preterm delivery between 34 and 37 weeks in 76 (6.3\%) patients. A total of 563 patients (46.8\%) underwent cesarean section. In 27 neonates $(2.2 \%)$ the 1 -minute Apgar score was $<7$ while 5-minute Apgar score was $<7$ in $17(1.4 \%)$ neonates. While $110(9.2 \%)$ infants were small for gestational age (SGA), 25 (2.1\%) were large for gestational age (LGA). Respiratory distress syndrome was detected in 47 (3.9\%) babies and sepsis was present in 32 (2.6\%). One hundred and twenty-seven $(10.6 \%)$ neonates required neonatal intensive care unit admission. 
The demographic features and perinatal outcomes of the study and control groups are demonstrated in Table 1. There was no difference between the two groups in gestational week at delivery, birth weight, rate of assisted reproductive techniques and adverse perinatal outcomes such as an Apgar score of $<7$ at the first and fifth minutes, SGA and LGA, presence of premature rupture of the membranes, preterm delivery, respiratory distress syndrome, neonatal sepsis and neonatal intensive care unit admission. Pre-eclampsia $(p<0.001), G D M(p<0.001)$, PP $(p=0.03)$ and intrauterine fetal death $(p<0.001)$ were more common and cesarean section rate was significantly higher $(p=0.02)$ in AMA group. Moreover, the number of gravida and parity of this group was higher as compared to controls.

The demographic features and perinatal outcomes of AMA and EAMA groups are presented in Table 2. In subgroup analysis, assisted reproductive techniques were more common in EAMA group ( $p<0.001)$. Furthermore, cesarean section rate was higher $(p<0.001)$, intrauterine fetal death $(p=0.04)$, PP $(p<0.001)$, pre-eclampsia $(p<0.001)$ and GDM $(p<0.001)$ were more common in EAMA group as compared to AMA group.

\section{Discussion}

The main findings of the study were as follows: 1) Pre-eclampsia, GDM, PP and intrauterine fetal death were more common and cesarean section rate was higher in AMA group as compared to controls, 2) In EAMA group, assisted reproductive techniques were more common as it was expected and in addition to this, cesarean section rate was higher, intrauterine fetal death, PP, pre-eclampsia and GDM were more common as compared to AMA group.

Advanced aged pregnancies have been gradually increasing all over the world during the last decades. Women have a tendency to postpone their childbearing due to their career goals and financial problems. Moreover, increased use of assisted reproductive techniques and effective birth control methods could be encountered as a risk factor for these pregnancies $(5,6)$.

Pregnancy at advanced ages may be unfavorable owing to maternal and fetal complications. Recent studies have demonstrated that AMA pregnancies are associated with adverse perinatal outcomes such as hypertensive disorders, GDM, preterm birth, placental abnormalities, increased cesarean section rates, low birth weight, macrosomia, low Apgar scores and perinatal

Table 1. Demographic features and perinatal outcomes of the study group

\begin{tabular}{|c|c|c|c|}
\hline & $\begin{array}{l}\text { Maternal age } \geq 35 \text { years } \\
(n=632)\end{array}$ & $\begin{array}{l}\text { Maternal age }<35 \text { years } \\
(n=570)\end{array}$ & $\mathrm{p}$ \\
\hline Gravida (n) & $4(2-7)$ & $2(1-4)$ & $<0.001$ \\
\hline Parity (n) & $3(1-7)$ & $1(1-4)$ & $<0.001$ \\
\hline Gestational week at birth (week) & $37(28-40)$ & $38(34-40)$ & 0.46 \\
\hline Birth weight (gram) & $3155.1 \pm 575.2$ & $3040.8 \pm 486.2$ & 0.71 \\
\hline Assisted reproductive technique $(n, \%)$ & $53(8.4 \%)$ & $16(2.8 \%)$ & 0.14 \\
\hline Intrauterine fetal death $(\mathrm{n}, \%)$ & $20(3.2 \%)$ & $14(2.4 \%)$ & $<0.001$ \\
\hline Placenta previa (n, \%) & $18(2.8 \%)$ & $9(1.6 \%)$ & 0.03 \\
\hline Pre-eclampsia $(n, \%)$ & $84(13.3 \%)$ & $24(4.2 \%)$ & $<0.001$ \\
\hline Gestational diabetes mellitus (n, \%) & $56(8.9 \%)$ & $19(3.3 \%)$ & $<0.001$ \\
\hline Premature rupture of membranes $(n, \%)$ & $42(6.6 \%)$ & $31(5.4 \%)$ & 0.27 \\
\hline Cesarean section $(n, \%)$ & $336(53.2 \%)$ & $227(39.8 \%)$ & 0.02 \\
\hline Apgar $1^{\text {st }} \min <7(n, \%)$ & $16(2.5 \%)$ & $11(1.9 \%)$ & 0.54 \\
\hline Apgar $5^{\text {th }} \min <7(n, \%)$ & $11(1.7 \%)$ & $6(1.1 \%)$ & 0.68 \\
\hline Respiratory distress syndrome $(n, \%)$ & $29(4.6 \%)$ & $18(3.2 \%)$ & 0.23 \\
\hline Neonatal sepsis $(n, \%)$ & $17(2.7 \%)$ & $15(2.6 \%)$ & 0.89 \\
\hline Neonatal intensive care unit admission $(n, \%)$ & $68(10.8 \%)$ & $59(10.4 \%)$ & 0.74 \\
\hline Preterm delivery $<34$ weeks $(n, \%)$ & $53(8.4 \%)$ & $43(7.5 \%)$ & 0.68 \\
\hline Preterm delivery $<34-37$ weeks $(n, \%)$ & $41(6.5 \%)$ & $35(6.1 \%)$ & 0.71 \\
\hline Small for gestational age ( $n, \%)$ & $64(10.1 \%)$ & $46(8.1 \%)$ & 0.17 \\
\hline Large for gestational age $(n, \%)$ & $16(2.5 \%)$ & $9(1.6 \%)$ & 0.43 \\
\hline
\end{tabular}


mortality (11). Furthermore, these adverse problems are more apparent in EAMA pregnancies $(13,14)$. It is known that AMA and EAMA pregnancies are linked with adverse perinatal outcomes, however, it is not clearly investigated which adverse outcome is more tightly related with AMA or EAMA.

Earlier studies reported an increased cesarean rate in AMA pregnancies. In our study, we found increased cesarean rate in AMA group as compared to controls, consistent with the literature. The cesarean rate was $53.2 \%$ in AMA group and $39.8 \%$ in control group. In a study by Berkowitz et al. (15), the cesarean rate was higher in AMA group and they claimed that this condition could probably be related to increased pregnancy complications such as hypertension, GDM and bleeding. Similar to our study, in another study from Nigeria evaluating only primigravid women, the cesarean rate was reported to be $58.1 \%$ in women older than 35 years while it was $32.1 \%$ in those younger than 35 years of age (16). Studies performed in our country demonstrated significantly higher cesarean rates for AMA pregnancies $(17,18)$. Another interesting finding of our study was the increased cesarean rate in EAMA group as compared to AMA group. Likewise, Hsieh et al. (13) reported an increased cesarean rate for both
AMA and EAMA groups and found a 1.6 fold increased risk for AMA group and 2.6 fold for EAMA group. In a study from Turkey by Cambaztepe et al. (19), the cesarean rate was found to be statistically significantly higher in EAMA group (65.7\%) than in those aged 20-35 years (40.2\%). Similarly, another study investigating the pregnancy outcomes of EAMA pregnancies reported a higher rate of cesarean section as compared to pregnancy in women aged 18-39 years (1). We assume that these higher cesarean rates could be related with increased pregnancy complications especially in primigravid patients and previous cesarean section and tubal ligation for multiparous women who desire permanent contraception. Due to repeated cesarean section, we found that PP was more common in AMA and EAMA pregnancies. In a study by Hsieh et al. (13), the prevalence of PP was $2.3 \%$ in AMA and $2.6 \%$ in EAMA group while it was significantly lower in $<35$ years with an incidence of $1 \%$. Supporting these results, Jacobsson et al. (20) claimed that women over 40 years of age had nearly 4 -fold increased risk of PP as compared to those under 40 years of age.

GDM is the most common metabolic disorder in pregnancy. Pancreatic beta cell function and insulin sensitivity decline with age and this condition leads to

\begin{tabular}{|c|c|c|c|}
\hline & $\begin{array}{l}\text { Advanced Maternal Age } \\
(\mathrm{n}=495)\end{array}$ & $\begin{array}{l}\text { Extremely Advanced Maternal Age } \\
(n=137)\end{array}$ & $\mathrm{p}$ \\
\hline Gravida (n) & $4(2-5)$ & $4(2-7)$ & 0.71 \\
\hline Parity (n) & $3(1-5)$ & $3(1-7)$ & 0.86 \\
\hline Gestational week at birth (week) & $37(32-40)$ & $36(28-39)$ & 0.54 \\
\hline Birth weight (gram) & $3270.47 \pm 634.2$ & $2980.3 \pm 524.1$ & 0.26 \\
\hline Assisted reproductive technique $(n, \%)$ & $32(6.5 \%)$ & $21(15.3 \%)$ & $<0.001$ \\
\hline Intrauterine fetal death $(n, \%)$ & $14(2.8 \%)$ & $6(4.4 \%)$ & 0.04 \\
\hline Placenta previa (n, \%) & $12(2.4 \%)$ & $6(4.4 \%)$ & $<0.001$ \\
\hline Pre-eclampsia $(n, \%)$ & $56(11.3 \%)$ & $28(20.4 \%)$ & $<0.001$ \\
\hline Gestational diabetes mellitus ( $n, \%)$ & $35(7.1 \%)$ & $21(15.3 \%)$ & $<0.001$ \\
\hline Premature rupture of membranes $(n, \%)$ & $33(6.6 \%)$ & $9(6.6 \%)$ & 0.91 \\
\hline Cesarean section ( $n, \%)$ & $240(48.5 \%)$ & $96(70.1 \%)$ & $<0.001$ \\
\hline Apgar $1^{\text {st }} \min <7(n, \%)$ & $12(2.4 \%)$ & $4(2.9 \%)$ & 0.67 \\
\hline Apgar $5^{\text {th }} \min <7(n, \%)$ & $8(1.6 \%)$ & $3(2.2 \%)$ & 0.34 \\
\hline Respiratory distress syndrome $(n, \%)$ & $23(4.6 \%)$ & $6(4.4 \%)$ & 0.58 \\
\hline Neonatal sepsis $(n, \%)$ & $13(2.6 \%)$ & $4(2.9 \%)$ & 0.49 \\
\hline Neonatal intensive care unit admission ( $n, \%)$ & $51(10.3 \%)$ & $17(12.4 \%)$ & 0.61 \\
\hline Preterm delivery $<34$ weeks $(n, \%)$ & $41(8.3 \%)$ & $12(8.8 \%)$ & 0.44 \\
\hline Preterm delivery $<34-37$ weeks $(n, \%)$ & $30(6.1 \%)$ & $11(8 \%)$ & 0.21 \\
\hline Small for gestational age $(n, \%)$ & $51(10.3 \%)$ & $13(9.5 \%)$ & 0.38 \\
\hline Large for gestational age (n, \%) & $11(2.2 \%)$ & $5(3.6 \%)$ & 0.11 \\
\hline \multicolumn{4}{|l|}{ n: Number } \\
\hline
\end{tabular}


high DM and GDM prevalence in advanced ages $(1,9,13)$. Previous studies searching the relationship between GDM and maternal age reported that GDM and pregestational diabetes were more common in advanced-age pregnancies $(1,21,22)$. Moreover, maternal age was claimed to be one of the independent predictors of GDM (9). Likewise, data from our country demonstrated similar results. Gunduz et al. (1) found that the prevalence of GDM was 12.5 fold increased in women aged over 40 years than in controls. Cambaztepe et al. (19) reported that the incidence of GDM in pregnant women at EAMA and those aged 2035 years was $5.9 \%$ and $1.1 \%$, respectively. In our study, GDM was more common when it was compared between pregnant women of advanced age and controls and also between women at AMA and EAMA.

Pre-eclampsia is another medical problem associated with AMA. In a study including 4193 patients with preeclampsia and eclampsia in Taiwan, AMA was claimed to be a risk factor for pre-eclampsia and 4.56 fold increased risk for pre-eclampsia was reported in pregnant women at AMA compared to pregnants younger than 35 years of age (23). Similarly, Gunduz et al. (1) reported that women at EAMA had 3.4 fold increased risk for pre-eclampsia compared to those younger than 40 years. We found that the prevalence of pre-eclampsia was higher both in AMA and EAMA groups in our study. In accordance with the literature, we suggest that the underlying mechanism for the aforementioned complication is probably due to uteroplacental vasculopathy. In their study investigating 62 autopsies, Naeye (24) demonstrated that the incidence of sclerotic pathologies in myometrial arteries increased with age. Furthermore, they reported that the incidence of sclerotic lesions was $61 \%$ at ages $30-39$ and $83 \%$ after age 39 . This vasculopathy may lead placental insufficiency which is the main pathophysiological mechanism for preeclampsia.

Another pathology that may lead to intrauterine fetal death is placental insufficiency. As it was expected, the risk of intrauterine fetal death was found to be higher in pregnant women of AMA in previous studies $(25,26)$. Similarly, we found that the incidence of intrauterine fetal death was higher not only in AMA group but also in EAMA pregnancies. The other explanation for this increment could be high fetal anomaly rates after 35 years of age.

\section{Study Limitations}

This retrospective study reported data from a single center reflecting the outcomes of pregnancies from a limited geographic region. To clarify the importance of advanced age on maternal and fetal outcomes, randomized controlled trials including more than one clinical center are required.

\section{Conclusion}

Adverse perinatal outcomes are more common in pregnant women of AMA and EAMA. We suggest that close monitoring of these pregnants in the antenatal period is crucial to avoid these adverse outcomes and to prevent possible maternal and fetal mortality and morbidities.

\section{Authorship Contributions}

Concept: B.D.Ç., B.D. Design: B.D., Ü.A.T. Data Collection or Processing: Ü.A.T. Analysis or Interpretation: B.D.Ç., B.D. Literature Search: Ü.A.T., B.D.Ç. Writing: B.D.Ç., B.D.

Conflict of Interest: The authors declare that they have no conflict of interest.

Financial Disclosure: The authors declared that this study received no financial support.

\section{References}

1. Gunduz S, Aslan Çetin B, Yalçın B, Atış Aydın A, Köroğlu N. Çok ileri Anne Yaşının Perinatal ve Neonatal Sonuçlara Etkisi. Turkiye Klinikleri J Gynecol Obst 2016;26:220-5.

2. Çetinoğlu EÇ, Canbaz S, Ağlan Z, Peşken Y. Samsun il Merkezi 2004 Yılı Illeri Yaş Gebelik Prevalansının Saptanması Ve Sonuçlarının Değerlendirilmesi. İnönü Üniversitesi Tıp Fakültesi Dergisi 2006;13:167-70.

3. Callaghan WM, Berg CJ. Pregnancy-Related Mortality Among Women Aged 35 Years and Older, United States, 1991-1997. Obstet Gynecol 2003;102:1015-21.

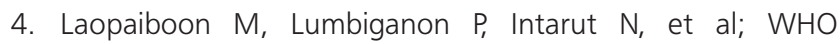
Multicountry Survey on Maternal Newborn Health Research Network. Advanced maternal age and pregnancy outcomes: a multicountry assessment. BJOG 2014;121:49-56.

5. Lampinen $R$, Vehvilainen-Julkunen $K$, Kankkunen P. A Review of Pregnancy in Women Over 35 Years of Age. Open Nurs J 2009;3:33-8.

6. Akyol A, Gedikbaşı A, Mağar V, Ark C, Ceylan Y. 40 yaş üstü gebeliklerin perinatal sonuçları. Perinatoloji Dergisi 2006;14:1-6.

7. Kara M, Yılmaz E, Töz E. Ağrı ilindeki 40 yaş üzeri gebelerin demografik özellikleri. J Turk Soc Obstet Gynecol 2010;7:1136.

8. Krieg SA, Henne MB, Westphal LM. Obstetric outcomes in donor oocyte pregnancies compared with advanced maternal age in in vitro fertilization pregnancies. Fertil Steril 2008;90:65-70.

9. Yogev Y, Melamed N, Bardin R, Tenenbaum Gavish K, BenShitrit G, Ben-Haroush A. Pregnancy outcome at extremely advanced maternal age. Am J Obstet Gynecol 2010;203:558. e1-7.

10. Jahromi BN, Husseini Z. Pregnancy outcome at maternal age 40 and older. Taiwan J Obstet Gynecol 2008;47:318-21.

11. Sohani V. Advanced maternal age and obstetric performance. Apollo Medicine 2009;6:258-63. 
12. Ziadeh S, Yahaya A. Pregnancy outcome at age 40 and older. Arch Gynecol Obstet 2001;265:30-3.

13. Hsieh TT, Liou JD, Hsu JJ, Lo LM, Chen SF, Hung TH. Advanced maternal age and adverse perinatal outcomes in an Asian population. Eur J Obstet Gynecol Reprod Biol 2010;148:21-6.

14. Ben David A, Glasser S, Schiff E, Segev Zahav A, Boyko V, Lerner-Geva L. Pregnancy and birth outcomes among primiparae at very advanced maternal age: At what price? Matern Child Health J 2016:20:833-42.

15. Berkowitz GS, Skovron ML, Lapinski RH, Berkowitz RL. Delayed childbearing and the outcome of pregnancy. N Engl J Med 1990;322:659-64.

16. Ojule JD, Ibe VC, Fiebai PO. Pregnancy outcome in elderly primigravidae. Ann Afr Med 2011;10:204-8.

17. Topçuoğlu S, Erçin S, Arman D, Gürsoy T, Karatekin G, Ovalı F. Adölesan veya İleri Anne Yaşı: Yenidoğan İçin Risk midir? Tek Bir Merkezin Retrospektif Sonuçları. Zeynep Kamil Tıp Bülteni 2014;45:131-5.

18. Sak S, Incebıyık A, Uyanıkoğlu H, Turp AB, Hilali NG, Sak ME. Tersiyer Bir Merkezde Doğum Yapan Adolesan, Reprodüktif ve Illeri Yaş Gebelerde Obstetrik ve Neonatal Sonuçların Karşılaştııılması. Zeynep Kamil Tıp Bülteni 2017;48:89-93.

19. Cambaztepe B, Yücel FD, Pektaş G, Bulut B, Uzun HC, Mihmanlı V. Kırk Yaş ve Üzeri Gebeliklerde Maternal ve
Neonatal Sonuçların Değerlendirilmesi. Okmeydanı Tıp Dergisi 2017;33:28-32.

20. Jacobsson B, Ladfors L, Milsom I. Advanced Maternal Age and Adverse Perinatal Outcome. Obstet Gynecol 2004;104:72733.

21. Delbaere I, Verstraelen H, Goetgeluk S, Martens G, De Backer G, Temmerman M. Pregnancy outcome in primiparae of advanced maternal age. Eur J Obstet Gynecol Reprod Biol 2007;135:41-6.

22. Luke B, Brown MB. Elevated risks of pregnancy complications and adverse outcomes with increasing maternal age. Hum Reprod 2007;22:1264-72.

23. Chen $C L$, Cheng $Y$, Wang $P H$, Juang CM. Review of preeclampsia in Taiwan: a multi-institutional study. Zhonghua Yi Xue Za Zhi (Taipei) 2000;63:869-75.

24. Naeye RL. Maternal age, obstetric complications, and the outcome of pregnancy. Obstet Gynecol 1983;61:210-6.

25. Jolly M, Sebire N, Harris J, Robinson S, Regan L. The risks associated with pregnancy in women aged 35 years or older. Hum Reprod 2000;15:2433-7.

26. Göker Tamay A, Güvenal T, Özgür N, Oruç Koltan S, Koyuncu FM. Retrospective Analysis of Advanced Maternal Age Pregnancies. Gynecol Obstet Reprod Med 2011;17:83-6. 